\title{
Phytochemical constituent and antimicrobial properties of guava extracts of east Hararghe of Oromia, Ethiopia
}

\author{
Dereje A. Oncho* ${ }^{*}$, Meseret C. Ejigu and Olyad E. Urgessa
}

\begin{abstract}
Background: There is a need for the screening more effective, affordable and readily available antimicrobial substances from local medicinal plants or herbs as the pathogenic bacteria are developing the resistance to common antibiotics. Guava (Psidium guajava L.) has antimicrobial activities and it is easily accessible to local populace in tropical region. Antimicrobial properties of guava extracts are attributed to the presence of different phytochemical constituents. The fact that phytochemicals' constituents vary as a result of geographical locations and literatures about Ethiopian guava with respect to phytochemicals' composition and content, and antimicrobial activities are hardly available, there is a need to analyze phytochemicals and antimicrobial properties of the Ethiopian guava from Oromia Regional State, Babile and Gursum Districts against Salmonella Typhi, Shigella boydii, Staphylococcus aureus and Enterococcus faecalis.
\end{abstract}

Methods: Extraction was done by maceration. Qualitative analysis of phytochemicals was carried out using standard protocol and quantitative phytochemical determination was conducted using spectrophotometric and gravimetric methods. Antimicrobial activities were determined by disc diffusion and broth dilution method.

Results: Qualitative phytochemical analysis revealed the presence of alkaloids, saponin, steroids and tannin, but the absence of flavonoid and phlobatannin in all Babile and Gursum leaf and bark extracts. Gravimetric measurement showed the highest terpenoid content of $105.00 \pm 8.66 \mathrm{mg}$ extract $/ \mathrm{g}$ of powder in Gursum leaf extract. Similarly, spectrophotometric measurement showed the highest total phenol content of $0.205 \pm 0.01 \mathrm{mg} / \mathrm{g}$ of the extracts as Tannic Acid Equivalent in Gursum leaf extract. Antimicrobial activity tests revealed that Babile leaf extract showed the highest $13.0 \pm 6.79 \mathrm{~mm}$ zone of inhibition against Shigella boydii compared to that of other guava extracts. Babile leaf extract showed the lowest $2.375 \pm 0.177 \mathrm{mg} / \mathrm{ml}$ minimum inhibitory concentration against Shigella boydii, while Gursum leaf extract showed the lowest $1.875 \pm 0.884 \mathrm{mg} / \mathrm{ml} \mathrm{MIC} \mathrm{against} \mathrm{Salmonella} \mathrm{Typhi.}$

Phytochemical analysis showed the presence of alkaloids, saponins, steroids and tannins in the all extracts, but the absence of flavonoids and phlobatannins in the all extracts and terpenoids in Babile extracts. The highest content of alkaloid and terpenoid ( $98.67 \pm 14.43,93.33 \pm 8.82 \mathrm{mg}$ extract/g of powder, respectively) were found in Babile leaf and Gursum bark extracts, respectively. Antimicrobial activity tests revealed that Babile leaf extracts showed higher zone of inhibition against all clinical isolates than that of Gursum leaf extracts, but Babile bark extracts showed lower zone of inhibition against all clinical isolates than that of Gursum bark extracts. Babile leaf extracts showed (Continued on next page)

\footnotetext{
* Correspondence: datomsa@yahoo.com

School of Biological Sciences and Biotechnology, College of Natural and Computational Sciences, Haramaya University, P. O. Box 138, Dire Dawa, Ethiopia
} 
(Continued from previous page)

the highest zone of inhibition $(13.0 \pm 6.79 \mathrm{~mm})$ against S. boydii, and Babile bark extracts showed the lowest

Minimum Inhibitory Concentration $(1.250 \pm 0.001 \mathrm{mg} / \mathrm{ml})$ against S. Typhi.

Conclusion: Guava extracts from different location could be source of natural antimicrobial agents with different composition and content. In vivo antimicrobial activity, and isolation, identification and synergy of specific active compound that responsible for the antibacterial activity should be evaluated.

Keywords: Antimicrobial activity, Ethiopia, Psidium guajava, Phytochemical analysis, Shigella boydii

\section{Background}

Plants produce a diverse array of secondary metabolites, many of which have antimicrobial activities against some pathogenic microorganisms that are implicated in enteric infections. Some of these compounds are constitutive, existing in healthy plants in their biologically active forms and they elicit chemotherapeutic or chemoprophylactic properties against a wide range of infectious enteric diseases [1]. Because of the pathogenic microorganisms are developing the resistance to common antibiotics, there is a need for the search of new antimicrobial agents mainly among plant extracts [2, 3]. Potential effort has been the screening of more effective, affordable and readily available antimicrobial substances with diverse chemical structures and novel mechanisms of action from local medicinal plants or herbs $[4,5]$.

P. guajava has been used traditionally as a medicinal plant throughout the world for a number of ailments [6, 7]. All parts of the plant have been used for different purposes: hepatoprotection, antioxidant, antiinflammatory, anti-spasmodic, anti-cancer, anti-microbial, anti-hyperglycemic, analgesic, endothelial progenitor cells, anti-stomachache and anti-diarrhea [7].

Phytochemical screening of different guava extracts has revealed numerous bioactive compounds. Guava leaf contains broad spectrum of bioactive compounds including tannin, flavonoid, terpenoid steroid, steroids, glycoside, cardiac glycoside, alkaloid, phlobatannin, polyphenol, saponin anthraquinones, Phytosteroid and carbohydrate [7-11]. The spectrum of bioactive compounds detected in bark extracts include anthraquinone alkaloids, tannin, saponin, flavonoid, steroid, terpenoids, cardiac glycosides, coumarin, carboxylic acid, quinine and resin [7, 12-15]. However, folklore involves the use of plants without isolating particular phytochemicals [16]. The reason is that the synergy of the combined substances enhances the efficacy [16-18] and dilutes toxicity [16]. But, detailed analysis of phytochemical constituents of medicinal plants makes dosage quantification more easy [16]. Guava is the single source of many beneficial components (probably the highest in number) of herbal remedies, which are edible without any known detrimental effect [19].
Development of antibiotics resistance by enteric bacterial pathogens including Salmonella and Shigella, against easily accessible and commonly prescribed drugs has become a major concern throughout the world, particularly in developing countries of East Africa including Ethiopia [20].

Besides the Methicillin Resistant Staphylococcus aureus (M.R.S.a) is an emerging bacterial pathogen associated with significant morbidity and mortality [21]. Similarly, the emergence of vancomycin-resistant Enterococci (VRE) is a cause of concern; as once established, it is very difficult to control [22]. Guava is one of the well known plants in folk medicine and it has been reported for the management of enteric bacterial infections. The antibacterial activities of guava extracts have been reported [1, 2, 14, 23-29].

The antibacterial properties of guava extracts were attributed to the presence of different phytochemical constituents [2, 9, 14, 27]. Variation in plant phytochemicals' constituents and antimicrobial activities exist, among other factors, due to biochemical reaction within species $[16]$, geographical location [30,31], methods of extraction $[8,29]$ and solvent used for extraction $[14,15,32,33]$.

The fact that phytochemicals' constituents vary as a result of geographical locations and literatures about Ethiopian guava with respect to phytochemicals' composition and content, and antimicrobial activities are hardly available, there is a need to analyze phytochemicals and antimicrobial properties of the Ethiopian guava from different districts for treatment of Salmonella Typhi, Shigella boydii, Staphylococcus aureus and Enterococcus faecalis infections. Therefore, this study was aimed to screen and quantify the major secondary compounds and to evaluate antibacterial activities of leaf and bark extracts of guava collected from Gursum and Babile districts. The two districts are part of East Hararghe Zone of Oromia, where guava is a common horticultural crop cultivated by small scale farmers [34]. The altitude of Babile Woreda ranges from 500 to $1500 \mathrm{~m}$ above sea level (m.a.s.l) [35]. Whereas, the altitude of Gursum woreda ranges from 1200 to 2950 m.a.s.l [36].

\section{Materials and methods}

\section{Plant material collection and authentication}

Fully mature and healthy guava ( $P$. guajava) leaves and barks were collected randomly from low land of area of 
Babile and mid-land area of Gursum in May 2014. Sample authentication was carried out at the Botany Laboratory and Herbarium of Haramaya University.

\section{Preparation of extract}

Leaves and barks were washed under running tap water to remove dusts and were dried under shade at room temperature for 15 days [11]. Thereafter, they were grounded to fine powder using electric miller (IKA A11 basic). The dry powders obtained were stored in air tight plastic containers and kept in refrigerator at $4{ }^{\circ} \mathrm{C}$ until they were used for qualitative analysis and extraction [33]. Modified method of [14] was used for extraction. Briefly, the dried powders were extracted by maceration using $97 \%$ ethanol. Eighty grams of powder and $400 \mathrm{ml}$ of ethanol were added to $500 \mathrm{ml}$ capacity Erlenmeyer flasks and mixed by shaking. Then, the flasks were wrapped with aluminum foil to avoid evaporation and were shaken on a platform shaker for 3 days at room temperature. Some of the resulting extracts were concentrated by heating on a hot plate at about 30 to $40^{\circ} \mathrm{C}$ for $30 \mathrm{~min}$ and were subsequently used for qualitative analysis. The rest were evaporated to dryness at room temperature for 4 days and preserved at $4{ }^{\circ} \mathrm{C}$ until used for qualitative and quantitative analysis, as well as for anti-bacterial activity tests.

\section{Qualitative phytochemical analysis}

Qualitative analysis of major group of secondary metabolites such as tannins, phlobatannins, saponins, flavonoids, steroids, terpenoids and alkaloids was carried out on the concentrated or solidified ethanolic extract, or powdered leaf and bark samples as described below.

1) Test for tannins: One gram of each powdered sample was separately added into $20 \mathrm{ml}$ of distilled water in test tubes. Then, the mixtures were boiled in water bath for 5 minutes and were filtered while hot using filter paper into Erlenmeyer flasks. After cooling, $1 \mathrm{ml}$ of the filtrate was diluted to $5 \mathrm{ml}$ solution using distilled water and then a few drops $(2-3)$ of $10 \%$ ferric chloride were added to it. Formation of bluish-black or brownish-green precipitate indicated the presence of tannins [37].

2) Test for phlobatannins: Zero point 5 gram of each solidified extract was placed into separate test tubes and mixed with $20 \mathrm{ml}$ of distilled water. The mixtures were boiled in water bath for $10 \mathrm{~min}$. After cooling, the mixture was separately filtered through a Whatman No 1 filter paper. Thereafter, $2 \mathrm{ml}$ of $1 \%$ aqueous hydrochloric acid was added to each mixture and shaken to develop red precipitate that indicates the presence of phlobatannins [38].
3) Test for saponins: One gram of each powdered sample was placed into separate test tubes and mixed with $10 \mathrm{ml}$ of distilled water. Then, the mixtures were boiled in a water bath for $10 \mathrm{~min}$ and were filtered while hot in to Erlenmeyer flask. After cooling, foam and emulsion were carried out. In foam test, $2.5 \mathrm{ml}$ of filtrate was added to a test tube, diluted to $10 \mathrm{ml}$ with distilled water and shaken vigorously for $2 \mathrm{~min}$. Formation of froth confirmed the presence of saponin in the filtrate. In emulsion test, 2 drops of olive oil were added to the frothing and the mixture was shaken vigorously for a few minutes. Formation of a fairly stable emulsion indicated the presence of saponins [38].

4) Test for flavonoids: Two $\mathrm{ml}$ of each of the concentrated ethanolic extract was added into different test tubes. Then, 4 drops of $10 \% \mathrm{NaOH}$ solution were added and heated in water bath for $10 \mathrm{~min}$. The intensity of yellow color which became colorless on addition of 10 drops of $1 \%$ hydrochloric acid showed the presence of flavonoids [39].

5) Test for steroids: Two $\mathrm{ml}$ chloroform and 10 drops of acetic acid were placed in a test tube. Then, $0.5 \mathrm{ml}$ of concentrated ethanolic extract was added to the test tube and mixed with the solvent. Next, $2 \mathrm{ml}$ of concentrated sulphuric acid was added from the side of the test tube. The change of red colour through blue to green indicated the presence of steroids [32].

6) Test for terpenoids: Five $\mathrm{ml}$ of each concentrated ethanolic extract was mixed with $2 \mathrm{ml}$ of chloroform in separate test tubes, and then $2 \mathrm{ml}$ of concentrated sulfuric acid was added carefully and shaken gently to form a layer. A reddish brown coloration of the inter-phase confirmed positive results for the presence of terpenoids [27].

7) Test for alkaloids: Two $\mathrm{ml}$ of $1 \% \mathrm{HCl}$ was added to $6 \mathrm{ml}$ of each concentrated ethanolic extract in different test tubes. Each mixture was heated for 2 min in a water bath while stirring continuously. It was then cooled and filtered. The resulting filtrate was tested with Mayer's Reagent for the presence of alkaloids as described by [39]. One $\mathrm{ml}$ of the filtrate was added to $0.5 \mathrm{ml}$ of Mayer's reagent. Formation of cream yellow precipitate indicated the presence of alkaloids.

\section{Quantitative phytochemical analysis}

After qualitative identification, the detected, major constituents of secondary metabolites such as total phenol, tannins, saponins, terpenoids and alkaloids were quantified as described below. 
1) Determination of total phenolics content: Spectrophotometric method was used to quantify total phenol content as described by [40]. Briefly, stock solution $(1 \mathrm{mg} / \mathrm{ml}, \mathrm{w} / \mathrm{v})$ was prepared by dissolving $10 \mathrm{mg}$ of the solidified leaf and bark extracts extract, separately, in $10 \mathrm{ml}$ of $80 \%$ ethanol. Then, $500 \mu \mathrm{l}$ stock of the extract was transferred to test tube. Next, $500 \mu \mathrm{l}$ of the Folin-Ciocalteu solution and $1 \mathrm{ml}$ of the sodium carbonate solution were added in the test tube. The final volume was adjusted to $10 \mathrm{ml}$ by adding $8 \mathrm{ml}$ of distilled water. The sample solutions were kept at room temperature for $30 \mathrm{~min}$ and their absorptions were measured at $760 \mathrm{~nm}$ using distilled water as a blank. Standard curve of tannic acid was used. Total Phenol Content (TPC) was calculated as tannic acid equivalent from a calibration curve of $\mathrm{y}=0.1167 \mathrm{x}+$ $0.0869, R^{2}=0.9627$ obtained from tannic acid concentration $(1,2,3,4$ and $5 \mu \mathrm{g} / \mathrm{mL})$.

2) Determination of tannin content: Five hundred $\mathrm{mg}$ of casein was transferred into each a $25 \mathrm{ml}$ capacity Erlenmeyer flasks. Then, $0.5 \mathrm{ml}$ stock solution of the extracts (prepared for determination of total phenol contents) and $5 \mathrm{ml}$ of distilled water were added in to the flask. After 2 hours, the extracts were filtered and these filtrates were used to determine non-tannic phenols using a procedure similar to total phenol determination. The tannin content was calculated as:

$\mathrm{TC}=\mathrm{TPC}-\mathrm{NTP}$

where $\mathrm{TC}$ is the tannin content in $\mathrm{mg} / \mathrm{g}$ of the extracts as Tannic Acid Equivalent (TAE), TPC is total phenolic content and NTP is Non-tannin Phenol content.

3) Determination of alkaloid content: Alkaloid content was determined using the method of [41]. Three gram of the powder was weighed and added into a $50 \mathrm{ml}$ capacity Erlenmayer flask. Then, $20 \mathrm{ml}$ of $10 \%$ acetic acid in ethanol was added into the flask which was soon covered and the solution was allowed to stand for $4 \mathrm{~h}$. Next, the solution was filtered and concentrated ammonium hydroxide was added drop wise to the filtrate until the formation of precipitate was stopped. The whole solution was then allowed to settle the precipitate. Then, precipitate was collected, washed with $10 \%$ ammonium hydroxide and then filtered. The obtained residue was dried and weighed. Alkaloid content was calculated as mg per grams of the sample powder used.
4) Determination of saponin content: Saponin content was determined using the method of [42]. Fifteen $\mathrm{ml}$ of $20 \%$ aqueous ethanol was added into a conical flask containing $3 \mathrm{~g}$ of the powder. It was then heated over a hot water bath for $4 \mathrm{~h}$ with continuous stirring at about $55^{\circ} \mathrm{C}$. After filtering the mixture, the residue was re-extracted with another $30 \mathrm{ml}$ of $20 \%$ ethanol. The resulting filtrates were combined and reduced to $10 \mathrm{ml}$ over water bath at about $90^{\circ} \mathrm{C}$. Then, it was transferred into a $250 \mathrm{ml}$ capacity separatory funnel and $5 \mathrm{ml}$ of diethyl ether was then added and the resulting mixture was shaken gently. The bottom aqueous layer was then drained. The top diethyl ether layer was washed using small quantities of water twice and aqueous layer was drained accordingly and combined. Thereafter, $15 \mathrm{ml} \mathrm{n}$-butanol was added to the combined aqueous layer solution and the resulting solution was shaken gently. The solution was washed twice with $2.5 \mathrm{ml}$ of $5 \%$ aqueous sodium chloride followed by discarding bottom aqueous layer while top n-butanol layer was transferred to pre-weighed petri-plate and heated in a water bath for evaporation. Then, samples were dried in the oven to at $60^{\circ} \mathrm{C}$ to constant weight and they were then measured; the saponin content was calculated as mg per grams of the sample extract used.

5) Determination of terpenoid content: Terpenoid content was determined using the method of [43]. Two grams of powder soaked in $50 \mathrm{ml}$ of $97 \%$ ethanol for 24h. The extracts were filtered using Whatman No.1 filter paper. The filtrate was added into separating funnel followed by addition $50 \mathrm{ml}$ of petroleum ether. The resulting mixture was shaken and allowed to stay for $5 \mathrm{~min}$ for layer formation. Then, the bottom layer was drained and discarded while top petroleum ether was collected and concentrated to dryness using rotary evaporator at $40^{\circ} \mathrm{C}$. The mass of dried ether extract, considered as crude terpenoid, was measured and its content was calculated as mg per grams of the sample powder used.

\section{Antimicrobial activity test Collection of enteric bacterial pathogens}

Enteric bacterial pathogens of human clinical isolate were obtained from Ethiopian Public Health Institute (EPHI), Addis Ababa, Ethiopia. The isolates include 2 gram-negative pathogen (Salmonella Typhi and Shigella boydii) and 2 gram-positive pathogens (Staphylococcus aureus and Enterococcus faecalis).

\section{Sub-culturing and standardization of inoculum}

Enteric bacterial suspension matched the turbidity of the 0.5 McFarland Standards were prepared as described by 
the Clinical Laboratory Standards Institute [44]. The resulting suspension was then used as inoculum for the test pathogen used in the antibacterial susceptibility test.

\section{Disc diffusion test}

A stock solution of the extract $(200 \mathrm{mg} / \mathrm{ml})$ was prepared by dissolving $0.4 \mathrm{~g}$ of each of the dried extracts in $2 \mathrm{ml}$ of ethanol.

Preparation of antibiotic impregnated discs: Whatman No.1 filter paper discs of $6 \mathrm{~mm}$ diameter were punched out with the aid of paper punch and were placed in petriplate. They were then sterilized by autoclaving at $121^{\circ} \mathrm{C}$ for $15 \mathrm{~min}$ [29]. After that, the discs were cooled and they were impregnated with $0.01 \mathrm{ml}$ of $200 \mathrm{mg} / \mathrm{ml}$ of each extract, and ethanol. The solution of the extract was prepared by dissolving $0.4 \mathrm{~g}$ of each of the dried extracts in $2 \mathrm{ml}$ of ethanol [25]. Enteric bacterial suspension matched the turbidity of the 0.5 McFarland Standards were prepared as described by the Clinical Laboratory Standards Institute [44].

Within 15 min after adjusting the turbidity of the suspension of inoculum, a sterile cotton swab was dipped into the adjusted suspension and rotated several times by pressing firmly on the inside wall of the tube above the fluid level.. Then, the dried surface of MHA plate was inoculated by streak plate method. Then, the MHA plates were left open for three to 5 minutes to allow for any excess surface moisture to be absorbed. Following this step, the impregnated discs were dispensed evenly and pressed onto the surface of the inoculated agar plate using sterile forceps [44].. Commercial ciprofloxacin discs $(5 \mu \mathrm{g})$ were used as a positive control and the pure solvent (ethanol) impregnated discs were used as a negative control. The MHA plates were then sealed with parafilm and incubated at $37^{\circ} \mathrm{C}$ for $24 \mathrm{~h}$. After incubation, the diameters of the zone of inhibition around each disc were measured to the nearest millimeter along two axes (i.e. $90^{\circ}$ to each other) by using transparent ruler and the means of the two readings were recorded. For each selected enteric bacterial isolate, the experiment was carried out in parallel and with three replications [27].

\section{Minimum inhibition concentration (MIC) determination}

A stock solution of extract $(20 \mathrm{mg} / \mathrm{ml})$ was prepared by dissolving $100 \mathrm{mg}$ of each of the dried extracts in $5 \mathrm{ml}$ of ethanol and from this stock; 2-fold serial dilutions of 10 , $5,2.5,1.25,0.625 \mathrm{mg} / \mathrm{ml}$ were prepared [25]. These concentrations, along with the stocks, were used for determination of minimum inhibitory concentration.

Broth dilution method was used for determination of Minimum Inhibitory Concentration (MIC). Breifly, $2 \mathrm{ml}$ of nutrient broth was added into six test tubes and 0.1 $\mathrm{ml}$ of the prepared concentration of each extract was mixed with the nutrient broth. Thereafter, $0.1 \mathrm{ml}$ of standardized inoculum was dispensed into the test tube containing the suspension of nutrient broth and the extract. Then, all test tubes were properly corked and incubated at $37^{\circ} \mathrm{C}$ for $24 \mathrm{~h}$. After which, they were observed for absence or presence of visible growth. The lowest concentration without visible growth of organisms was regarded as the MIC [29].

\section{Statistical analysis}

All quantitative phytochemical analysis and disc diffusion antibacterial activity test were conducted in triplicate. The experimental results were expressed as means \pm Standard Error of the Mean $(n=3)$. MIC determination was carried out in duplicate and the experimental results were expressed as mean \pm Standard Deviation $(n=2)$. The data were analyzed by SPSS version 20 and the means were separated by Duncan's multiple range tests. The difference among the means of the measured variables was considered at $p<0.05$.

\section{Results}

Qualitative phytochemical analysis of the extract

The results of qualitative phytochemical analysis revealed the presence of alkaloids, saponin, steroids and tannin in all leaf and bark sample. Whereas, flavonoid and phlobatannin were absent in the all guava extracts and terpenoid was absent in the Babile guava extracts (Table 1).

\section{Quantitative phytochemical determination of the extract}

The result of quantitative determination of phytochemicals was summarized in Table 2. Total Phenolic Content (TPC) and Tannin Content (TC) were obtained from regression equation of the calibration curve $y=0.1167 x+$ $0.0869 \mathrm{mg} / \mathrm{g}$ as TAE as shown in Fig. 1. As can be seen from Table 2, TPC and TC of Babile bark extract $(0.13 \pm 0.00 \mathrm{mg} / \mathrm{g}$ as TAE and $0.09 \pm 0.01 \mathrm{mg} / \mathrm{g}$ as TAE, respectively) were significantly the lowest as compared to other guava extracts $(p<0.05)$. Alkaloid content of Babile and Gursum leaf extracts, Babile and Gursum bark extracts, and saponin contents of all guava leaf and bark extracts were not significantly different $(p>0.05)$.

\section{Antibacterial activity of the extract}

The result of agar disc diffusion test was summarized in Table 3. Babile leaf extracts showed significantly the highest ZOI $(8.7 \pm 1.01 \mathrm{~mm})$ against Salmonella Typhi $(p>0.05)$. Compared to other antimicrobial agents, the standard antibiotics (ciprofloxacin) showed significantly the highest ZOI against all tested clinical isolates ( $\mathrm{p}>$ $0.05)$.

The results of MICs of the extract were represented in Table 4. As it can be seen from the table, the lowest MIC of Babile leaf extract was against Shigella boydii 
Table 1 Results of phytochemical screening from ethanolic extracts of guava leaf and bark

\begin{tabular}{llllllll}
\hline Plant & \multicolumn{7}{l}{ Screened phytochemicals } \\
\cline { 2 - 7 } & Tannin & Saponin & Flavonoid & Alkaloid & Steroid & Terpenoid & Phlobatannin \\
\hline Babile leaf & + & + & - & + & + & - & - \\
Babile bark & + & + & - & + & + & - & - \\
Gursum leaf & + & + & - & + & + & + & - \\
Gursum bark & + & + & - & + & + & + \\
\hline
\end{tabular}

+indicates the presence and -the absence of screened phytochemicals

$(2.375 \pm 0.177 \mathrm{mg} / \mathrm{ml})$, while the lowest MIC of Gursum leaf extract was against Salmonella Typhi $(1.875 \pm 0.884$ $\mathrm{mg} / \mathrm{ml})$. Both Babile and Gursum bark extracts showed the lowest MIC against $S$. Typhi.

\section{Discussion}

\section{Phytochemical analysis}

In the present study, a preliminary qualitative phytochemical analysis was carried out to identify the major secondary metabolites such as tannin, phlobatannins, saponins, flavonoids, steroids, terpenoids and alkaloids.. The result of qualitative analysis was shown in Table 1. Alkaloids, saponins, steroids and tannins were detected in all leaf and bark guava extracts, but flavonoids and phlobatannins were not detected in the all extracts, and terpenoids in the Babile leaf and bark extracts. Qualitative phytochemical analysis was conducted by several researchers on guava extracts obtained by macerating leaf powder in ethanol. In one study, the presence of phenols, tannins, terpenoids, flavonoids and glycosides, and absences of saponins were revealed in the leaf collected from Fort Valley State University, USA [27]. The presence of terpenoids, quinones, oil \& fat, phenol, and the absence of alkaloids, flavonoids, sterols and anthocyanin were shown in the leaf collected from India [32]. The presence of alkaloids, flavonoids, phenols, tannins, and the absences of saponins, steroids, terpenoids and cardiac glycosides were indicated in the leaf collected from Baringo Counties, Kenya [33]. Leaves were collected from Botanical garden of Department of Biological Sciences, Bayero University, Kano, Nigeria and presence of alkaloid, glycosides, saponins and tannins detected in the leaf extract obtained by ethanol percolation at $30^{\circ} \mathrm{C}$, and the absence of flavonoid and steroids [29]. The presence of phlobatannins, saponin, flavonoids, steroids, terpenoids, polyphenol and glycosides, and the absence of triterpenoids, alkaloid and anthraquinone were shown in the leaf collected from Thanjavur, Tamil Nadu, India [11].

Similarly, qualitative phytochemical analysis was conducted on the guava bark collected from different regions. Barks were collected from Elele in Kelga Local Government Area of Rivers State, Nigeria and alkaloids, anthraquinone, cardiac glycosides, flavonoids, tannins and saponins were detected in the bark powder [12]. Extraction was done by soaking powder of bark collected from Bodinga, Nigeria and the presence of tannin, saponin, flavonoid, alkaloid, steroid, terpenoids, and cardiac glycosides were revealed in the extract [14]. Extraction was done by Soxhlet method from bark collected university of Maiduguri, Borno state Nigeria and presence of tannis, cardiac glycoside, flavonoids, terpenoid and saponins, and the absence of anthraquinone and alkaloid were shown in the extract [15].

Quantitative determination of alkaloid, terpenoid, total phenolics and tannin contents were carried out and the result of quantities analysis was shown in Table 2 .

Gursum guava extracts had generally higher contents of most quantified phytochemicals than Babile guava extracts even though most differences were insignificant $(p>0.05)$. The alkaloid content of Babile bark extract $(72.33 \pm 3.93 \mathrm{mg} / \mathrm{g})$ was lower than the alkaloid content of Gursum bark extract $(82.33 \pm 8.67 \mathrm{mg} / \mathrm{g})$. The saponin content of Babile leaf extract $(29.00 \pm 4.93 \mathrm{mg} / \mathrm{g})$ was lower than the saponin content of Gursum leaf extract $(30.00 \pm 5.77 \mathrm{mg} / \mathrm{g})$. Babile bark extract showed

Table 2 Quantity of phytochemicals of ethanolic extracts of guava leaf and bark

\begin{tabular}{lllll}
\hline Phytochemical & Babile leaf & Babile bark & Gursum leaf & Gursum bark \\
\hline Alkaloid* $^{*}$ & $98.67 \pm 14.43^{\mathrm{a}}$ & $72.33 \pm 3.93^{\mathrm{b}}$ & $84.33 \pm 1.33^{\mathrm{ab}}$ & $82.33 \pm 8.67^{\mathrm{ab}}$ \\
Saponin* $^{*}$ & $29.00 \pm 4.93^{\mathrm{a}}$ & $19.00 \pm 5.86^{\mathrm{a}}$ & $30.00 \pm 5.77^{\mathrm{a}}$ & $19.00 \pm 7.57^{\mathrm{a}}$ \\
Terpenoid* $^{\text {N }}$ & $\mathrm{NP}$ & $105.00 \pm 8.66^{\mathrm{a}}$ & $93.33 \pm 8.82^{\mathrm{a}}$ \\
Total Phenol $^{\ddagger}$ & $0.20 \pm 0.01^{\mathrm{a}}$ & $0.13 \pm 0.00^{\mathrm{b}}$ & $0.205 \pm 0.01^{\mathrm{a}}$ & $0.20 \pm 0.01^{\mathrm{a}}$ \\
Tannin $^{*}$ & $0.15 \pm 0.01^{\mathrm{a}}$ & $0.09 \pm 0.01^{\mathrm{b}}$ & $0.16 \pm 0.02^{\mathrm{a}}$ & $0.16 \pm 0.01^{\mathrm{a}}$ \\
\hline
\end{tabular}

*is amount in $\mathrm{mg}$ extract/g of powder; $\neq$ is amount in $\mathrm{mg} / \mathrm{g}$ of the extracts as Tannic Acid Equivalent; NP is not present. The values are Mean \pm Standard error of mean $(n=3)$. Small letters superscript compares between means in row, and means with similar small letters show no significant difference, whereas means with different small letters show significant difference at $p<0.05$ 


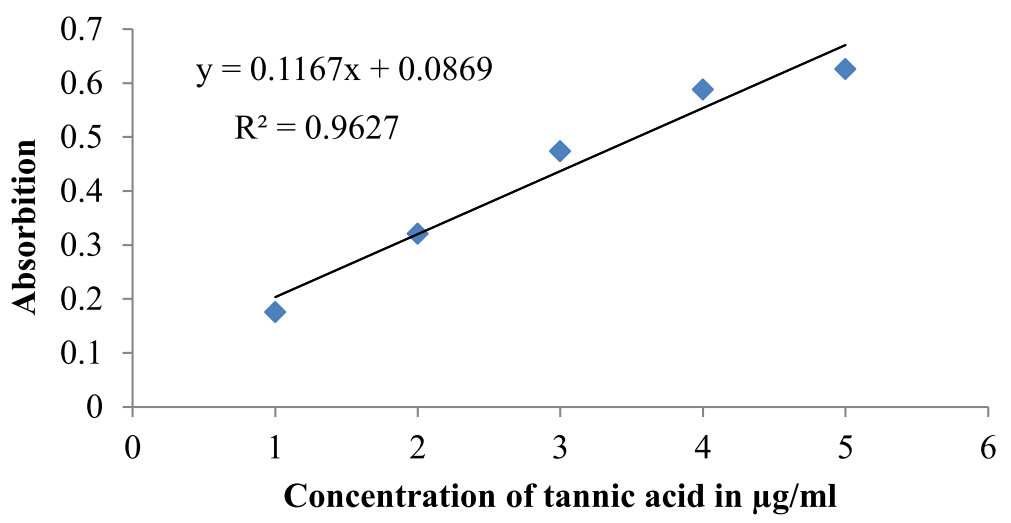

Fig. 1 Concentration-response curve of tannic acid standard at $760 \mathrm{~nm}$

significantly lower TPC $(0.13 \pm 0.00 \mathrm{mg} / \mathrm{g}$ as TAE $)$ and TC $(0.09 \pm 0.01 \mathrm{mg} / \mathrm{g}$ as TAE $)$ than that of Gursum bark extract $(p<0.05)$. The results of phytochemical analysis revealed slight variation in type and content of the investigated phytochemicals between Babile and Gursum districts. This was supported by previously study [30].

Quantitative phytochemical analysis of guava collected from different regions and extracted using ethanol was reported previously. In one study, total alkaloid extracted from leaves collected from Afaka, NDA permanent site, Kaduna, Nigeria and the obtained product was $20 \mathrm{mg} / \mathrm{g}$ of powder [26]. Extraction was done by soaking leaf and bark collected from South Western part of Nigeria and the obtained extract showed concentrations of tannin $(11.54 \pm 0.14$ $\mathrm{mg} / \mathrm{g})$, polyphenol $(1.67 \pm 0.24 \mathrm{mg} / \mathrm{g})$, alkaloid $(59.85 \pm$ $0.34 \%)$ and saponin $(1.86 \pm 0.15 \%)$ in the leaf extract, whereas concentrations of tannin $(3.85 \pm 0.14 \mathrm{mg} / \mathrm{g})$, polyphenol $(0.45 \pm 0.20 \mathrm{mg} / \mathrm{g})$, alkaloid $(6.65 \pm 0.15 \%$ $\mathrm{mg} / \mathrm{g})$ and saponin $(1.03 \pm 0.15 \%$ in the bark extracts [16]. Extraction was done by soxhlet apparatus and TPC of $7.30 \pm 0.05 \mathrm{mg}$ of catechol equivalent/g dry materials were obtained from the twig extract [9].

The results of phytochemical analysis in present study and that of the above mentioned as previous studies revealed differences for the same plant species. it was reported that the results of phytochemical analysis may differ because of various factors such as biochemical reaction within species [16], genes, environment and their interactions [31], plant genotypes, developmental stages and geographical locations [30], extraction methods $[8,29]$. Furthermore, variations in extraction methods are usually found in the length of the extraction period, $\mathrm{pH}$, temperature, particle size, and the solvent-to-sample ratio [45].

\section{Antibacterial activity}

In the present study, antibacterial activity tests were carried out using agar disc diffusion and broth dilution methods. Agar disc diffusion method was first used to identify sensitivity of the clinical isolates to the extracts. Once the extracts were found to have antibacterial activity through ZOI formation, broth dilution method was used to determine MIC. The ZOI of the tested clinical isolates was shown in Table 3. Babile and Gursum guava extracts at concentration of $2 \mathrm{mg} /$ disc showed inhibitory effect on all tested clinical isolates. The standard antibiotics (ciprofloxacin) showed significantly higher ZOI against all the isolates than all guava extracts. Comparing antibacterial activity of guava extracts against each

Table 3 The antimicrobial activities of leaf and bark extracts of guava on bacterial clinical isolates

\begin{tabular}{lllll}
\hline $\begin{array}{l}\text { Antimicrobial } \\
\text { agent }\end{array}$ & \multicolumn{3}{l}{ Zone of inhibition in $\mathbf{~ m m}$ on clinical isolates } \\
\cline { 2 - 5 } & S. Typhi & S. boydii & S. aureus & E. faecalis \\
\hline Babile leaf & $8.7 \pm 1.01^{\mathrm{Aa}}$ & $13.0 \pm 6.79^{\mathrm{Ab}}$ & $9.7 \pm 0.44^{\mathrm{Aab}}$ & $10.7 \pm 1.59^{\mathrm{Aab}}$ \\
Babile bark & $7.0 \pm 0.29^{\mathrm{Aa}}$ & $10.6 \pm 0.79^{\mathrm{Ab}}$ & $7.3 \pm 0.60^{\mathrm{Aa}}$ & $8.0 \pm 0.29^{\mathrm{Aa}}$ \\
Gursum leaf & $7.6 \pm 0.36^{\mathrm{Aa}}$ & $11.0 \pm 0.25^{\mathrm{Ab}}$ & $9.0 \pm 0.50^{\mathrm{Aa}}$ & $9.0 \pm 0.76^{\mathrm{Aa}}$ \\
Gursum bark & $7.3 \pm 0.33^{\mathrm{Aa}}$ & $12.0 \pm 0.29^{\mathrm{Ab}}$ & $10.0 \pm 1.00^{\mathrm{Aab}}$ & $9.0 \pm 1.26^{\mathrm{Aa}}$ \\
Ciprofloxicin & $25 \pm 1.32^{\mathrm{Ca}}$ & $35.8 \pm 1.20^{\mathrm{Bb}}$ & $39.7 \pm 1.42^{\mathrm{Bb}}$ & $25.0 \pm 2.75^{\mathrm{Ba}}$ \\
Ethanol & ZD & ZD & & $Z$ \\
\hline
\end{tabular}

The values are Mean \pm Standard error of mean $(n=3)$. Capital letter superscript compares between means in column, and means with similar capital letters represent no significant difference, whereas means with different capital letters are significantly different at $p<0.05$. Small letter superscript compares between means in row, and means with similar small letters show no significant difference, whereas means with different small letters show significant difference at $p<$ 0.05. 'ZD' is zero diameters 
Table 4 The minimum inhibitory concentrations of guava leaf and bark extracts against bacterial clinical isolates

\begin{tabular}{lllll}
\hline \multirow{2}{*}{$\begin{array}{l}\text { Guava } \\
\text { extracts }\end{array}$} & \multicolumn{2}{l}{ MIC values for clinical isolates in $\mathbf{~ m g} / \mathbf{m l}$} & & \\
\cline { 2 - 5 } & S. Typhi & S. boydii & S. aureus & E. faecalis \\
\hline Babile leaf & $2.500 \pm 0.001^{\mathrm{A}}$ & $2.375 \pm 0.177^{\mathrm{A}}$ & $5.000 \pm 0.001^{\mathrm{A}}$ & $10.00 \pm 0.001^{\mathrm{B}}$ \\
Babile bark & $1.250 \pm 0.001^{\mathrm{A}}$ & $2.500 \pm 0.001^{\mathrm{A}}$ & $7.500 \pm 3.536^{\mathrm{A}}$ & $7.500 \pm 3.536^{\mathrm{AB}}$ \\
Gursum leaf & $1.875 \pm 0.884^{\mathrm{A}}$ & $2.500 \pm 0.001^{\mathrm{A}}$ & $3.750 \pm 1.768^{\mathrm{A}}$ & $7.500 \pm 3.536^{\mathrm{AB}}$ \\
Gursum bark & $1.250 \pm 0.001^{\mathrm{A}}$ & $3.125 \pm 2.652^{\mathrm{A}}$ & $2.500 \pm 0.001^{\mathrm{A}}$ & $3.750 \pm 1.768^{\mathrm{A}}$ \\
\hline
\end{tabular}

The values are Mean \pm Standard deviation $(n=2)$. Letters superscript compares between means in column, and means with similar letters show no significant difference, whereas means with different letters show significant difference at $p<0.05$

clinical isolates, Babile leaf extracts showed the highest ZOI against $S$. Typhi $(8.7 \pm 1.01 \mathrm{~mm}), S$. boydii $(13.0 \pm$ $6.79 \mathrm{~mm})$ and $E$. faecalis $(10.7 \pm 1.59 \mathrm{~mm})$ and Gursum bark extracts showed the highest ZOI against $S$. aureus $(10.0 \pm 1.00 \mathrm{~mm})$. This was happened may be due to the presence of a significant amount of alkaloid in Babile leaf extracts, the synergy of higher content of alkaloid and terpenoids in Gursum bark extracts and the degree of sensitivity of the isolates to the extracts. All the guava extracts showed the highest ZOI against $S$. boydii and the lowest zone of inhibition against $S$. Typhi. The antibacterial activity of Babile leaf and bark extracts was effective against the clinical isolates in order of S. boydii > E. faecalis $>S$. aureus $>S$. Typhi. The order of Gursum leaf and Gursum bark extracts were S. boydii $>E$. faecalis $=S$. aureus $>S$. Typhi and $S$. boydii $>S$. aureus $>E$. faecalis $>S$. Typhi, respectively.

MICs of the extracts were determined by preparing double serial dilutions. The ethanol extracts were dried and re-dissolved in mixture of ethanol and water in order to prepare the extracts' double dilutions ranging from $20 \mathrm{mg} / \mathrm{ml}$ to $0.625 \mathrm{mg} / \mathrm{ml}$. The MIC values of the guava extracts were shown in Table 4. All guava extracts showed different MIC against each clinical isolates. MIC of Babile leaf and Gursum bark extracts against $E$. faecalis was significantly different $(p<0.05)$. All the guava extracts showed the lowest MIC against $S$. Typhi, except Babile leaf extracts that showed the lowest MIC against S. boydii. The antibacterial activity of Babile leaf and bark extracts measured by MIC was effective against the clinical isolated in order of $S$. boydii $>S$. Typhi. $>$ E. faecalis $>S$. aureus and $S$. Typhi $>S$. boydii $>S$. aureus $>E$. faecalis, respectively. The order of Gursum leaf and Gursum bark extracts were $S$. Typhi $>$ S. boydii $>S$. aureus $>$ E. faecalis and $S$. Typhi $>S$. aureus $>S$. boydii $>E$. faecalis, respectively. The difference in MIC among tested guava extracts is may be due to the difference in individual concentrations of constituents of phytochemicals that made up overall tested concentration of leaf and bark extracts and susceptibility of the isolates to the extracts' constituent in a concentration dependent pattern as previously reported [26].
The composition and quantity of alkaloids, saponins, tannins and terpenoids both in leaf and bark extracts of guava have medical implications that may be responsible for the observed antibacterial activities. Previous research report showed antibacterial activity of tannin [46], alkaloid [26], saponin [47, 48] and terpenoid [18, 49].

For guava collected from different regions, bark and leaf ethanolic extracts were shown to have in vitro antimicrobial activity against numerous bacteria in previous studies. Leaf was collected from Fort Bhaktapur, Kathmandu Valley, Nepal and the extract obtained from Soxhlet method showed 13, 20, $14 \mathrm{~mm}$ ZOI against $S$. typhi, Salmonella paratyphi and Shigella spp. [1]. In another study, antimicrobial activity of leaf extract showed $11.0 \pm 0.52 \mathrm{~mm}$ ZOI against S. aureus [27]. Antimicrobial activity of extract of leaf was carried out using well diffusion method and the results showed 3, 7, 6, 5 and $4 \mathrm{~mm}$ ZOI against S. typhi, Salmonella paratyphi A, Salmonella paratyphi B, Shigella sonnei, Shigella dysentarie, respectively [2]. Antimicrobial activity of extract of leaf was carried out using disc diffusion and broth dilution methods. The results showed that extract obtained by ethanol percolation at $30^{\circ} \mathrm{C}$ inhibited Salmonella spp. and Staphylococcus spp. by $8 \mathrm{~mm}$ and the MIC of the extract were $0.25 \mathrm{mg} / \mathrm{ml}$ and $>1 \mathrm{mg} / \mathrm{ml}$ against Salmonella spp. and Staphylococcus spp., respectively [29]. Antimicrobial activity of extract of stem bark showed $12 \pm$ $0.85 \mathrm{~mm}$ and $22 \pm 0.96 \mathrm{~mm}$ ZOI against Salmonella spp. and $S$. aureusat $100 \mathrm{mg} / \mathrm{ml}$, respectively, [14].

\section{Conclusions}

Phytochemical analysis revealed that Babile and Gursum guava leaf and bark extracts showed slight variation in composition and content of phytochemicals' constituents. The presence of various medicinally important phytochemicals' constituents in Babile and Gursum guava leaf and bark extracts and the contents of the constituents might be responsible for the observed, broad inhibitory effect on growth of both gram-positives and gram-negatives enteric bacterial pathogens. Therefore, guava leaf and bark extracts could be seen as a good source for useful drugs and an alternative medicine in 
the treatment of enteric disorders. Since the current work is a screening of major group of phytochemicals and In vitro antimicrobial activity of crude extract, further investigation is required to isolate and characterize specific phytochemicals present in the Babile and Gursum leaf and bark extracts to discover the most effective compounds that probably encourage the future search of novel antimicrobial agents and natural drug development from guava. Furthermore, evaluation of In vivo antimicrobial activity and synergy investigation are important for incorporation of guava leaf and bark extracts into regiment of natural antimicrobial agents.

\section{Abbreviations}

m.a.s.l: Meter above sea level; TPC: Total Phenol Content; TC: Tannin Content; EPHI: Ethiopian Public Health Institute; ZOl: Zone of inhibition; MHA: Mueller Hinton Agar; MIC: Minimum Inhibition Concentration

\section{Acknowledgements}

The authors are grateful to the Haramaya University, Ethiopia for funding the research work, providing necessary instrumental and other supports.

\section{Authors' contributions}

DAO carried out the planning or developing of the title, drafting of the proposal and helped in laboratory work and editing of this research paper. $M C$ revised, coordinated and supervised the research work. DAO, MCE, and OEU carried out the collection of plant materials. OE carried out all part of the experiment, analyzed and interpreted the data and was a major contributor in writing the manuscript. All authors read and approved the final manuscript.

\section{Funding}

This work was financially supported by grants from Haramaya University, Office of the Research Affairs.

\section{Availability of data and materials}

The dataset used and/or analyzed during the current study are available from the corresponding author on reasonable request.

\section{Declarations}

Ethics approval and consent to participate

Not applicable.

\section{Consent for publication}

Not applicable.

\section{Competing interests}

The authors declare that they have no competing interests.

Received: 25 June 2020 Accepted: 1 April 2021

Published online: 12 April 2021

\section{References}

1. Omojate GC, Enwa FO, Jewo AO, Eze CO. Mechanisms of antimicrobial actions of phytochemicals against enteric pathogens - a review. J Pharm Chem Biol Sci. 2014;2(2):77-85.

2. Bajracharya AM, Yami KD, Prasai T, Basnyat SR, Lekhak B. Screening of some medicinal plants used in Nepalese traditional medicine against enteric Bacteria. Sci World. 2008;6(6):107-10.

3. Bansode DS, Chavan MD. Screening of guava (Psidium gaujava) for effective Phytomedicines and study on its antimicrobial effect against selected enteric pathogens. Int J Adv. 2014;3(3):802-6.

4. Adekunle AS, Adekunle OC. Preliminary assessment of antimicrobial properties of aqueous extract of plants against infectious diseases. Bio Medical. 2009;1(3):20-4.

5. Bhatia A, Nishu K, Yogita T. Diversity in antimicrobial activity of some medicinal plants of high altitude area: Achyranthes aspera, Thalictrum foliolosum, Valeriana wallichii, Hedychium spicatum, Woodfordia fruticosa, Acorus calamu, Eupatorium Cannabium. Asian J Plant Res. 2012;2(5):638-42.

6. Joseph B, Priya RM. Review on nutritional, medicinal and pharmacological properties of Centella asiatica ( Indian pennywort ). Int J Pharma Bio Sci. 2011;2(1):54-69.

7. Barbalho SM, Farinazzi-machado FMV, Goulart RDA, Cláudia A, Brunnati S, Machado AM. Psidium Guajava (guava): a plant of multipurpose medicinal applications. Med Aromat Plants. 2012;1(4):104-9.

8. Porwal V, Singh P, Gurjar D. A comprehensive study on different methods of extraction from Guajava leaves for curing various health problem. Int J Eng Res. 2012;2(6):490-6.

9. Chetia J, Upadghyaya S, Dkbal S. Value of Young Twig of Psidium Guagava Linn. From Dibrugarh, Assam. Int J Pharm Pharm Sci. 2014;6(Suppl 2):843-6.

10. Krishnarathi A, Issac SS, Kannan M. Phytochemical analysis of selected plant leaves consumed by the Folivory bats in Tirunelveli. J Environ Appl Bioresearch. 2014;02(01):14-8

11. Thenmozhi S, Rajan S. GC-MS analysis of bioactive compounds in Psidium guajava leaves. J Pharmacogn Phytochem. 2015;3(5):162-6.

12. Okunrobo OL, Imafidon EK OKoye KM. Phytochemical screening, proximate and metal content analysis of the stem bark of phytochemical screening, proximate and metal content analysis of the stem bark of Psidium guajava Linn, (Myrtaceae). African J Pharm Res Dev. 2012;4(1):12-5.

13. Velmurugan S, Michael Babu M. Punitha, S. M J, Thanga Viji V, Citarasu T. screening and characterization of antiviral compounds from Psidium guajava Linn. Root bark against white spot syndrome virus. Indian J Nat Prod Resour. 2012;3(2):208-14.

14. Abdulhamid A, Fakai IM, Sani I, Argungu AU, Bello F. Preliminary phytochemical and antibacterial activity of ethanolic and aqueos stem bark extracts of Psidium guajava. Am J drug Discov Dev. 2014;4(1):85-9.

15. Tijjani MA, Shettima YA, Busuguma U, Askira AY, Dungus MH, Dungus MH, et al. Proximate, elemental content and preliminary phytochemical screening of Psidum guajava Linn stem bark. Int J Med Chem Anal. 2012:4(4):222-5.

16. Obaineh $\mathrm{O}$, Shadrach A. Phytochemical constituents and medicinal properties of different extracts of Anacardium occidentale and Psidium guajava. Asian J Biomed Pharm Sci. 2013;3(16):20-3.

17. Jana S, Shekhawat GS. Phytochemical analysis and antibacterial screening of in vivo and in vitro extracts of Indian medicinal herb: Anethum graveolens. Res J Med Plant. 2010:4:206-2012.

18. Munyendo WLL, Orwa JA, Rukunga GM, Bii CC. Bacteriostatic and bactericidal activities of Aspilia mossambicensis, Ocimum gratissimum and Toddalia asiatica extracts on selected pathogenic bacteria. Res J Med Plant. 2011;5(6):717-27.

19. Rahim N, Gomes DJ, Watanabe H, Rahman SR, Chomvarin C, Endtz HP, et al. Antibacterial activity of Psidium guajava leaf and bark against multidrugresistant vibrio cholerae: implication for cholera control. Jpn J Infect Dis 2010;63(4):271-4.

20. Omulo S, Thumbi SM, Njenga KM, Call DR. A review of 40 years of enteric antimicrobial resistance research in Eastern Africa: what can be done better? Antimicrob Resist Infect Contr. 2015. https://doi.org/10.1186/s13756-0140041-4.

21. Blasi F. A typical pathogens and respiratory tract infections. Eur Respir J. 2004;24(1):171-81. https://doi.org/10.1183/09031936.04.00135703.

22. Sood S, Meenakshi M, Das BK, Arti K. Enterococcal infections and antimicrobial resistance. Indian J Med Res. 2008;128(2):111-21.

23. Sanches NR, Aparício D, Cortez G, Schiavini MS, Nakamura CV, Prado B, et al. An evaluation of antibacterial activities of Psidium guajava (L.). Brazilian Arch Biol Technol. 2005:48(3):429-36. https://doi.org/10.1590/S1516-89132 005000300014.

24. Choudhury S, Sharan L, Sinha MP. Phytochemical and antimicrobia screening of Psidium Guajava L. leaf extracts against clinically important gastrointestinal pathogens. J Nat Prod Plant Resour. 2012;2(4):524-9.

25. Esimone CO, Anthony AA, Kwaliafon SM, Nneka NI, Kennedy FC. Antimicrobial activity of Psidium guajava Linn. Stem bark extracts against methicillin-resistant Staphylococcus aureus. African J Biotechnol. 2012;11(89): 15556-9.

26. Garba S, Okeniyi SO. Antimicrobial activities of total alkaloids extracted from some Nigerian medicinal plants. J Microbiol Antimicrobials. 2012;4(3):60-3.

27. Biswas B, Rogers K, Mclaughlin F, Daniels D, Yadav A. Antimicrobial Activities of Leaf Extracts of Guava ( Psidium guajava L .) on Two GramNegative and Gram-Positive Bacteria. Int J Microbiol. 2013. https://doi. org/10.1155/2013/746165 
28. Zahidah WZ, Noriham A, Zainon MN. Antioxidant and antimicrobial activities of pink guava leaves and seeds. J Trop Agric Food Sci. 2015;41(1): $53-62$.

29. Taura DW, Yusha'u M, Bello UA, Hassan A, Saidu JPT. Antibacterial activity of Psidium guajava in clinical isolates. Acad J Microbiol Res. 2014;2(2):079-83.

30. Penuelas J, Llusia J. The complexity of factors driving volatile organic compound emissions by plants. J Plant Biol. 2001;44(4):481-7. https://doi. org/10.1023/A:1013797129428.

31. Moore BD, Rose LA, Carsten K, William JF. Explaining intraspecific diversity in plant secondary metabolites in an ecological context. New Phytol. 2014; 201(3):733-50. https://doi.org/10.1111/nph.12526.

32. Gayathri V, Kiruba D. Preliminary phytochemical analysis of leaf powder extracts of. Int J Pharmacogn Phytochem Res. 2014;6(2):332-4.

33. Geoffrey KK, John KM, Naomi M, Simon KM. Qualitative Phytochemical Screening of Camellia sinensis and Psidium guajava Leave Extracts from Kericho and Baringo Counties. Int J Adv Biotechnol Res. 2278;5:976-2612.

34. Milaku J. Patterns and determinants of fruit and vegetable demand in developing countries: a multi-country comparison (Ethiopia), In FAO/WHO, fruit and vegetables for health, report of a joint FAO/WHO workshop 1-3 September 2004, Kobe, Japan, vol. 2005; 2005

35. Tessema YA, Aweke CS, Endris GS. Understanding the process of adaptation to climate change by small-holder farmers: the case of east Hararghe Zone, Ethiopia. Agric Food Econ. 2013;1:13.

36. Abdurezak M, Haimanot D, Tadele K, Tilahun Z, Girma K. Prevalence of gastrointestinal nematodes of sheep in Gursum Woreda of eastern Hararghe zone, Oromia regional state, Ethiopia. Researcher. 2015;7(8):45-54.

37. Ajayi IA, Ajibade O, Oderinde RA. Preliminary phytochemical analysis of some plant seeds. Res J Chem Sci. 2011;1(3):58-62.

38. Shaik S, Nisha S, Ashley N. Comparison of the selected secondary metabolite content present in the cancer-bush Lessertia frutescens (Sutherlandia) L. extracts. African J Trad Comple Alt Med. 2011;8(4):429-34.

39. Adachukwu IP, Ogbonna AO, Eze FU. Phytochemical analysis of paw-paw (Carica papaya L.) leaves. Int J Life Sci Biotechnol Pharma Res. 2013;2(3):348jmv 351.

40. Amorim ELC, Castro VTNA, Melo JG, Correa AJC, Sobrinho TJSP. Standard operating procedures (SOP) for the spectrophotometric determination of phenolic compounds contained in plant samples. In: Akyar l, editor. Latest research into quality control. London: IntechOpen; 2012. https://doi.org/10. $5772 / 51686$.

41. Harborne JB. Phytochemical methods. 2rd ed. London: Chapman and Hall, Ltd.; 1973.

42. Obadoni BO, Ochuko PO. Phytochemical studies and comparative efficacy of the crude extracts of some homeostatic plants in Edo and Delta states of Nigeria. Global J Pure Appl Sci. 2001;86:2003-8.

43. Ferguson NM. A text book of Pharmacognosy, Pp.191. New Delhi: Mac Milan Company; 1956.

44. Frankil RC, Matthew AW, Jeff A, Michael ND, George ME, Mary JF, et al. Performance standards for antimicrobial disk susceptibility tests: approved standard. 11th ed. Wayne: Clinical Laboratory Standards Institute; 2012

45. Ncube NS, Afolayan AJ, Okoh Al. Assessment techniques of antimicrobial properties of natural compounds of plant origin: current methods and future trends. Afr J Biotechnol. 2008;7(12):1797-806. https://doi.org/10. 5897/AJB07.613

46. Mariita RM, Ogol CKPO, Oguge NO, Okemo PO. Methanol extract of three medicinal plants from samburu in northern Kenya show significant antimycobacterial, antibacterial and antifungal properties. Res J Med Plant. 2011;5:54-64.

47. Soetan KO, Oyekunle MA, Aiyelaagbe OO, Fafunso MA. Evaluation of the antimicrobial activity of saponins extract of Sorghum bicolor L. Moench. Afr J Biotechnol. 2006:5(23):2405-7.

48. Maatalah BM, Kambuche BN, Bellahouel S, Merah B, Fortas Z, Soulimani R, et al. Antimicrobial activity of the alkaloids and saponin extracts of Anabasis articulate. E3 J Biotechnol Pharma Res. 2012;3(3):54-7.

49. Sibi G, Chatly P, Adhikari S, Ravikumar KR. Phytoconstituents and their influence on antimicrobial properties of Morinda citrifolia L. Res J Med Plant. 2012;6(6):441-8. https://doi.org/10.3923/rjmp.2012.441.448.

\section{Publisher's Note}

Springer Nature remains neutral with regard to jurisdictional claims in published maps and institutional affiliations.

\section{Submit your manuscript to a SpringerOpen ${ }^{\circ}$ journal and benefit from:}

- Convenient online submission

- Rigorous peer review

- Open access: articles freely available online

- High visibility within the field

- Retaining the copyright to your article

Submit your next manuscript at $\boldsymbol{\nabla}$ springeropen.com 